\title{
Caddoan Archaeology in the Little Cypress Creek Valley: Recent Investigation at the Griffin Mound Site (41UR142), Upshur County, Texas
}

Bo Nelson

Heritage Research Center, Stephen F. Austin State University

Timothy K. Perttula

Heritage Research Center, Stephen F. Austin State University

Mike Turner

Follow this and additional works at: https://scholarworks.sfasu.edu/ita

Part of the American Material Culture Commons, Archaeological Anthropology Commons, Environmental Studies Commons, Other American Studies Commons, Other Arts and Humanities Commons, Other History of Art, Architecture, and Archaeology Commons, and the United States History Commons

Tell us how this article helped you.

This Article is brought to you for free and open access by the Center for Regional Heritage Research at SFA ScholarWorks. It has been accepted for inclusion in Index of Texas Archaeology: Open Access Gray Literature from the Lone Star State by an authorized editor of SFA ScholarWorks. For more information, please contact cdsscholarworks@sfasu.edu. 


\section{Caddoan Archaeology in the Little Cypress Creek Valley: Recent Investigation at the Griffin Mound Site (41UR142), Upshur County, Texas}

\section{Creative Commons License}

\section{(c) (1) (8)}

This work is licensed under a Creative Commons Attribution-NonCommercial 4.0 International License 


\title{
CADDOAN ARCHAEOLOGY IN THE LITTLE CYPRESS CREEK VALLEY: RECENT INVESTIGATIONS AT THE GRIFFIN MOUND SITE (41UR142), UPSHUR COUNTY, TEXAS
}

\author{
Bo Nelson, Tim Perttula, and Mike Turner
}

\section{INTRODUCTION}

As part of the long-term study of the prehistoric archaeology of the Caddo peoples in Northeast Texas, we are currently focusing our investigations on the Little Cypress Creek valley in Upshur County. Although poorly known archaeologically (Thurmond 1985, 1990), background research conducted to date, discussions with landowners, and selected surveylimited testing efforts over the last few years indicates that there are extensive Archaic and
Caddoan archaeological remains preserved in the Little Cypress Creek valley (Nelson 1993; Nelson and Perttula 1993a, 1993b; Horizon Environmental Services, Inc. 1993, 1994). Caddoan period archaeological sites (ca. A.D. 800-1600) are particularly common. The investigations of one of the more significant Caddoan sites found to date in the valley, the Griffin Mound site (41UR142), is the subject of this paper.

\section{SITE}

The Griffin Mound site is a natural mound situated at the base of a steeply sloping upland landform in the Caney Creek valley. Caney Creek, about $220 \mathrm{~m}$ from the site itself, flows southeast about $10 \mathrm{~km}$ to its confluence with Little Cypress Creek north of the community of Enon.

The mound is about $1-1.5 \mathrm{~m}$ in height and covers approximately

\section{SETTING}

$900 \mathrm{~m}^{2}$ (ca. 0.2 acres). Currently, the site is in a pasture. The site surface is pocked with gopher mounds, and a feeder station has disturbed a small area. Based on excavation profiles, the natural mound is composed of $80 \mathrm{~cm}$ of a dark brown sandy loam midden deposit overlying a yellowish-brown sandy loam/loam that extends to at least $130 \mathrm{~cm}$ below the present ground surface.

\section{INVESTIGATIONS}

The Griffin Mound was recorded by Bo Nelson in the summer of 1992. He noted the presence of cultural materials on the surface of the natural mound, primarily exposed on gopher mounds. The disturbed soil in the gopher mounds was stained black, which he thought was indicative of subsurface midden deposits. Collected from the site's surface were 260 artifacts: 27 ceramic sherds (including two engraved rim sherds and six decorated body sherds). 205 pieces of lithic debris, two quartzite cobbles, one core, one arrowpoint fragment, a dart point, one piece of daub, and 22 animal bones or bone fragments.

During the summer of 1993, the authors (with the assistance of 
Volume 5, Number 3

Bob D. Skiles, then of the U.S. Forest Service, Lufkin, Texas, and Joshua $S$. Nelson) excavated four shovel tests and a single $1 \times 1 \mathrm{~m}$ unit at the site to better define the site's vertical extent, and to determine the integrity and content of midden deposits apparent on the naturai mound (Figure 1). Shovel tests actually documented that the midden is distributed over most of the natural mound, with these cultural deposits ranging from ca. $38-92 \mathrm{~cm}$ in thickness; the shallowest deposits are present along the eastern side of the mound nearest the base of the uplands.

Shovel test 4 had a noticeably higher density of artifacts, as well as large sherds and numerous faunal remains, than the other shovel tests, and most of the artifacts occurred deep in the deposits. This suggested that the shovel test had encountered a cultural feature and/or artifact concentration. Accordingly, a $1 \times 1$ $m$ unit was laid out immediately adjacent to the shovel test to investigate the potential cultural feature.

The $1 \times 1 \mathrm{~m}$ unit, Test Unit 5 , was excavated in $10 \mathrm{~cm}$ levels within recognizable cultural strata (i.e., plow zone and midden) using shovel and trowel; all soil matrix was screened through 1/4-inch mesh hardware cloth.

The excavations first documented a $20 \mathrm{~cm}$ thick plow zone (Zone 1) of brown sandy loam; artifact density in the plow zone was $135 / \mathrm{m}^{3}$ (primarily lithic debris and pottery sherds). Zone 2 is a $60 \mathrm{~cm}$ thick midden of dark brown sandy loam. Artifact density in the midden increased to $300 / \mathrm{m}^{3}$, with lithic debris, faunal remains, pottery sherds, and charred nutshells particularly common.

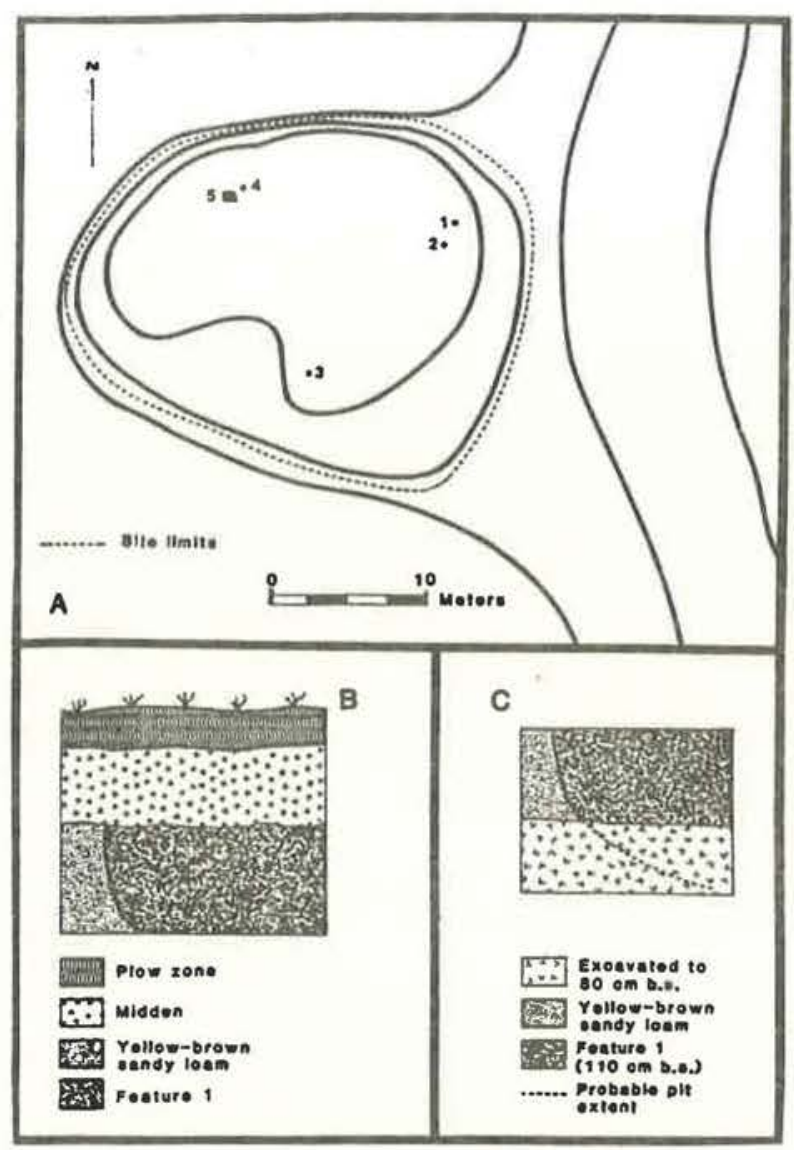

Figure 1. Investigations at the Griffin Mound site. IA, Site map showing locations of shovel tests and Unit $5 ; 1 B$, Schematic profile of Unit 5; 1C, Plan view of Feature 1 at $110 \mathrm{~cm} \mathrm{b. \theta .,} \mathrm{Te日t} \mathrm{Unit} 5$.

As the excavations progressed to greater depths, the soil became increasingly water-saturated. This made excavating and screening the test unit difficult and tedious, but did help to heighten the contrast between the midden and the underlying yellowish-brown sediments when the unit reached approximately $80 \mathrm{~cm}$ below surface (bs). At that depth, the edges of a large pit (Feature 1) were visi- 


\section{CADDOAN ARCHEOLOGY NEWSLETTER}

ble in the floor of the unit (Figure 2). The pit fill (a black sandy loam) proved to have abundant cultural materials (600 artifacts $\left./ \mathrm{m}^{3}\right)$, principally charred nutshells, pottery sherds, lithic debris, and faunal remains. A radiocarbon sample of charred nutshells was secured between 110-130 $\mathrm{cm}$ in the feature, while a sample of 20 liters of feature fill was collected between 80-90 cm bs.

Feature 1 was excavated by sectioning it along an east-west line, and removing the cultural deposits in only the northern half of Test Unit 5; excavations at 80 $\mathrm{cm}$ bs in the southern half of the unit, and at $130 \mathrm{~cm}$ bs in feature fill in the northern half. The total depth of Feature 1 was not determined because the feature fill below $130 \mathrm{~cm}$ bs was extremely saturated and virtually impossible to properly excavate. Rather than risk damaging the lower feature deposits, excavations in Test Unit 5 were terminated at $130 \mathrm{~cm}$ bs. The unit was then backfilled, and the ground surface returned to its original contour.

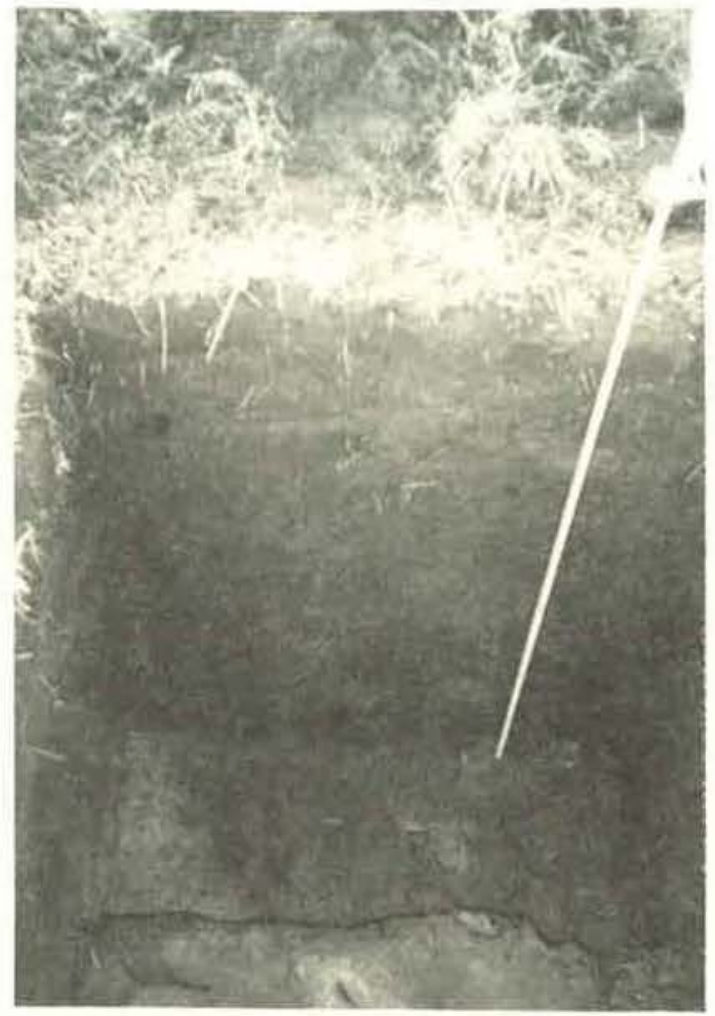

Figure 2. Feature 1 pit outline visible in floor of Test Unit 5 at $80 \mathrm{~cm} \mathrm{b.} 6$.

\section{FEATURES}

A large pit was identified in Test Unit 5 at a depth of $80 \mathrm{~cm}$; this is at the base of the midden. The pit fill was a black sandy loam (10YR 2/1) with occasional yellow-brown mottles. Based on the plan of the feature as exposed in the unit's floor, the pit extent is about $2 \mathrm{~m}$ in diameter. Feature 1 is at least $50 \mathrm{~cm}$ deep $(80-130$ $\mathrm{cm}$ bs); its total depth was not ascertained because the pit fill below $130 \mathrm{~cm}$ was too saturated to excavate.

We speculate that Feature 1 represents a storage facility, simi- lar to those seen on Caddoan sites from the Sabine River to the Red River. In fact, large unlined pit features have been noted to occur in proximity to Caddoan structures throughout the region.

There is no evidence of heating, or in situ firing activities within the feature, and there are no discrete lenses of trash in the fill. Although the feature is filled with homogeneous midden deposits, we would not expect that trash dumping was its primary function because it would be a considerable expenditure of effort 
to excavate a large pit for trash disposal when the rest of the extensive midden debris on the site was clearly simply dumped on the ground surface and then built up to an appreciable thickness over time. That the feature fill is comprised of midden sediments probably indicates that upon abandonment of the feature, it became filled with surrounding midden deposits.

\section{ARTIFACT ASSEMBLAGE}

The surface collection, shovel testing, and $1 \times 1 \mathrm{~m}$ unit excavations recovered 946 artifacts and 680 pieces of charred nutshells and faunal remains. The greatest amount of artifacts and subsistence remains come from the contents of Feature 1, the large pit with abundant amounts of charred nutshells, fauna, and burned clay/daub pieces (Table 1). To date, the nutshells and faunal remains have not been identified or analyzed by the appropriate specialists.

\section{LITHIC ARTIFACTS}

Lithic debris. The largest category of lithic artifacts from Griffin Mound is the lithic debris $(n=477)$, the flakes and chips from tool manufacture and resharpening activities. The flotation results indicate that small $<1 \mathrm{~cm}^{2}$ in size) pieces of lithic debris are particularly common in the Feature 1 fill (Table 1). Cortical pieces comprise about $18 \%$ of the lithic debris.

The vast majority of the debris $(88 \%)$ is on locally obtained quartzite, petrified wood, hematite, ferruginous sandstone, and cherts. The local cherts and quartzites (ca. $85 \%$ of the debris) are reddish-brown, light tan, gray, rust red, and yellow in color, and they are similar in appearance to lithic raw materials obtained in terrace and stream gravels. Hematite $(0.4 \%)$, ferruginous sandstone $(1.7 \%)$, and petrified wood $(2.1 \%)$ occur in low numbers in the lithic debris, although these types of raw material are usually well represented in Late Archaic occupations in the region (Perttula et al. 1986). The few pieces of firecracked rock are on coarse-grained quartzites.

The possible nonlocal lithic debris includes small flakes of some Red River gravel cherts $(5.7 \%)$ and grayish-white, orange, and reddishbrown novaculite $(5.7 \%)$. Most of the nonlocal debris was collected from the surface of the site; in excavated contexts from Test Unit 5, these materials represent only about $5 \%$ of the lithic debris sample. The low frequency of nonlocal materials in the Griffin Mound lithic debris is consistent with Middle-Late Caddoan assemblages in the Lake Fork and Little Cypress Creek basins (Perttula et al. 1993; Horizon Environmental Services, Inc. 1994).

Groundstone tools. The groundstone tools $(n=7)$ are made on locally available ferruginous sandstone and hematite raw materials. Among the ferruginous sandstone pieces are three fragments of grooved abraders (Surface; TU 5, 60-70 cm; TU 5, 110-130 cm), one mano/grinding stone (TU 5, 60-70 cm), and a mano/pitted stone (TU 5, 110-130 cm). The hematite groundstone tools include a fragment of a grooved axe (Surface), and part of a pigment stone (TU 5, 100-110 cm).

Uniface. There is one unifacially retouched tool in the Griffin Mound lithic tool assemblage 
(TU 5, 20-30 cm). The tool is made on a small ( $15.5 \times 9 \mathrm{~mm}$ ) local red quartzite noncortical flake.

Cores. The four cores are from small cobbles. Three (ST 1; TU 5, 40-50 cm and 60-70 cm) are of local quartzites, and have only a few flake removals with large amounts of cortex remaining on the pieces. The other core, of a light gray chert that may have its source in Red River gravels (Banks 1990; Bruseth and Perttula 1981), is bipolar with multiple flake removals and no cortex remaining.
The bipolar technique of core reduction works well in removing flakes from small pieces of raw material, and has been noted in several Early and Middle Caddoan assemblages in Northeast Texas.

Projectile points. Projectile points, especially arrowpoints, are apparently abundant at the Griffin Mound site, based on the limited investigations conducted to date. Eleven arrowpoints (eight from Unit 5, six of which were in Feature 1) and two dart points (including one in Feature 1) were

Table 1. Artifacts recovered from the Griffin Mound site.

\begin{tabular}{|c|c|c|c|c|c|c|c|c|c|c|c|c|}
\hline Unit. & $\begin{array}{l}\text { Lithic } \\
\text { debris }\end{array}$ & $\begin{array}{l}\text { Cores/ } \\
\text { tools }\end{array}$ & $\mathrm{AP*}$ & DP* & $\begin{array}{l}\text { Sher } \\
\text { plain }\end{array}$ & $\begin{array}{l}\text { da } \\
\text { Dec. }\end{array}$ & GS* & $\mathrm{FCR}$ * & NS* & Bone & $\begin{array}{l}\mathrm{BC} * / \\
\text { Daub }\end{array}$ & Total \\
\hline Surface & 205 & $1 /-$ & 1 & 1 & 19 & $B$ & 2 & - & - & 22 & 1 & 260 \\
\hline ST1 & - & $1 /-$ & - & - & 2 & 3 & - & - & - & 9 & - & 15 \\
\hline ST2 & 7 & - & - & - & 2 & - & - & - & = & 3 & - & 12 \\
\hline ST3 & 8 & - & - & - & 1 & - & - & - & 2 & 4 & 1 & 16 \\
\hline ST4 & 28 & - & 2 & - & 9 & 2 & - & 1 & - & 12 & - & 54 \\
\hline \multicolumn{13}{|c|}{ Unit 5 (cm bs) } \\
\hline $0-20$ & 17 & - & - & - & 4 & 5 & - & 1 & - & 5 & - & 32 \\
\hline $20-30$ & 10 & $-/ 1$ & - & - & 2 & - & - & 2 & - & 4 & - & 19 \\
\hline $30-40$ & 2 & - & 1 & - & 4 & - & - & - & - & 9 & - & 16 \\
\hline $40-50$ & 14 & $1 /-$ & 1 & - & 5 & 1 & - & 2 & 2 & 26 & 2 & 54 \\
\hline $50-60$ & 22 & - & - & - & 4 & 1 & - & 1 & 6 & 10 & 1 & 45 \\
\hline $60-70$ & 22 & $1 /-$ & - & - & 8 & - & 2 & - & 12 & 10 & . & 55 \\
\hline $70-80$ & 30 & - & 3 & - & 11 & 1 & - & 2 & 8 & 7 & 2 & 64 \\
\hline $80-90$ & 19 & - & 1 & - & 7 & - & - & - & 17 & 22 & - & 66 \\
\hline $80-90 \mathrm{~F} \star \star$ & 51 & - & 1 & - & 6 & - & - & - & 345 & 63 & 247. & 713 \\
\hline $90-100$ & 10 & - & - & 1 & 11 & - & - & - & 13 & 4 & 7 & 46 \\
\hline $100-110$ & 8 & - & - & - & 4 & - & 1 & - & 4 & 1 & 1 & 20 \\
\hline $110-130$ & 24 & - & 1 & - & 34 & 1 & 2 & 5 & 54 & 6 & 13 & 142 \\
\hline TOTAL & 477 & $4 / 1$ & 11 & 2 & 133 & 22 & 7 & 14 & 463 & 217 & 275 & 1626 \\
\hline
\end{tabular}

* $A P=$ arrowpoint $; D P=$ dart point $;$ GS = groundotone $; \quad F C R=$ fire cracked rock; $N S=$ nutshell; $B C=$ burned clay

** Flotation vample 
Volume 5, Number 3

recovered during our investigations (Figure 3; Table 1).

The arrowpoints from Griffin Mound are all rather small in size (range of 12-27 $\mathrm{mm}$ in length and 8-17 mm in width), are on both local (67\%) and non-local (33\%) raw materials (Ouachita Mountains cherts from Red River gravels), and usually have pronounced resharpened blades with prominent barbs. Typologically identifiable forms include one Alba (ST 4; Figure 3b), one Colbert (Unit 5, 30-40 cm; Figure 3d), and three Catahoula arrowpoints (two from 70-80 cm in Unit 5 and one from 110-130 cm in Feature 1; Figure $3 c, e, g$; Turner and Hester 1993). Five arrowpoint fragments (one proximal, one proximal-medial, one distal, two tip fragments) and one complete arrowpoint are not identifiable to type, although the complete specimen (Unit 5, 40-50 $\mathrm{cm})$ resembles the Bonham type (Figure 3a). Bonham, Catahoula, and Alba arrowpoint types have been found in association with Middle Caddoan ceramics at several components in the Cypress Creek Basin (Thurmond 1990:227). The Colbert type occurs in Early and Middle Caddoan contexts in Northeast Texas and Western Louisiana (Turner and Hester 1993; Fields et al. 1993).

There are two rather wide, thick Gary dart points in the artifact assemblage. The one from the surface (Figure 3i) is broader and thicker, whereas the point from Unit 5 (90-100 cm in Feature 1) has been extensively resharpened along the blade. Both Gary points are made on local heat-treated quartzites.

The occurrence of Gary points on Northeast Texas sites is usually indicative of Late Archaic and Early Ceramic period occupation. The landform on which the site is found is sufficiently old that
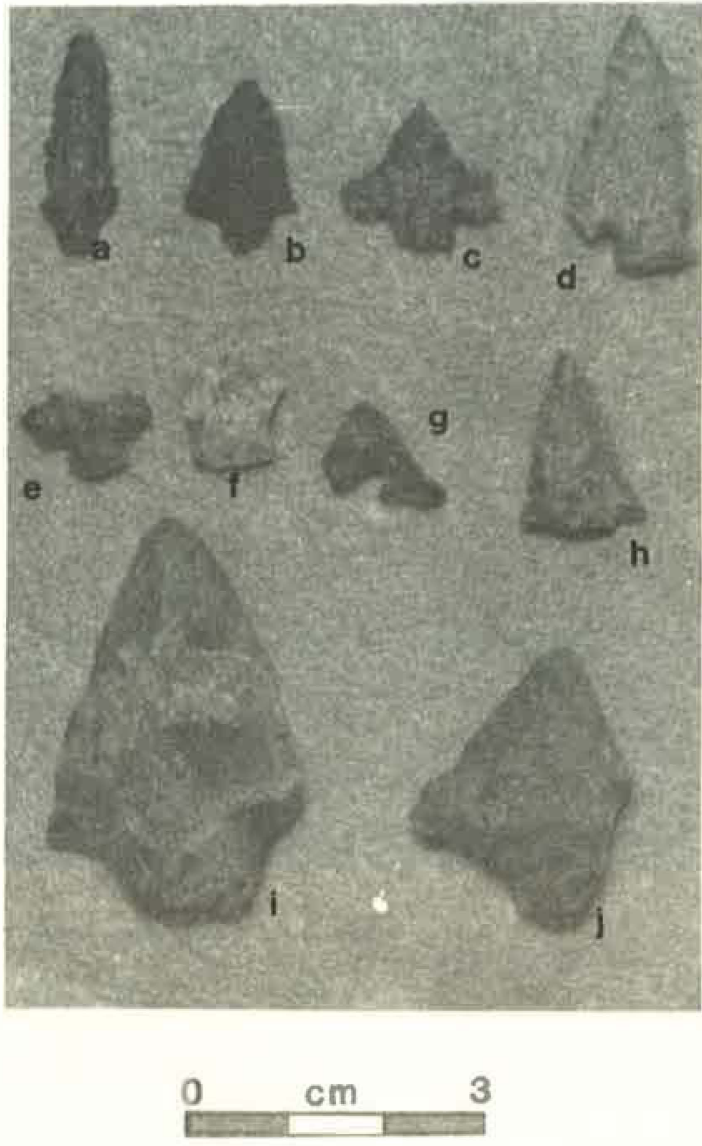

Figure 3. Projectile points from the Griffin Mound site: Alba, $3 b$; Colbert, 3d; Catahoula, $3 c, e, g$; unidentified arrowpoints $3 f, h$; Gary, $3 i, j$.

there could well have been a sparse Late Archaic and/or Early Ceramic period occupation preceding the Middle Caddoan settlement at Griffin Mound. Nevertheless, the recovery of a Gary point in the pit fill of Feature 1, apparently filled with surrounding Middle Caddoan midden deposits, suggests that this resharpened Gary may well have been reused as a knife or cutting tool by the Caddoan inhabitants of the site; 


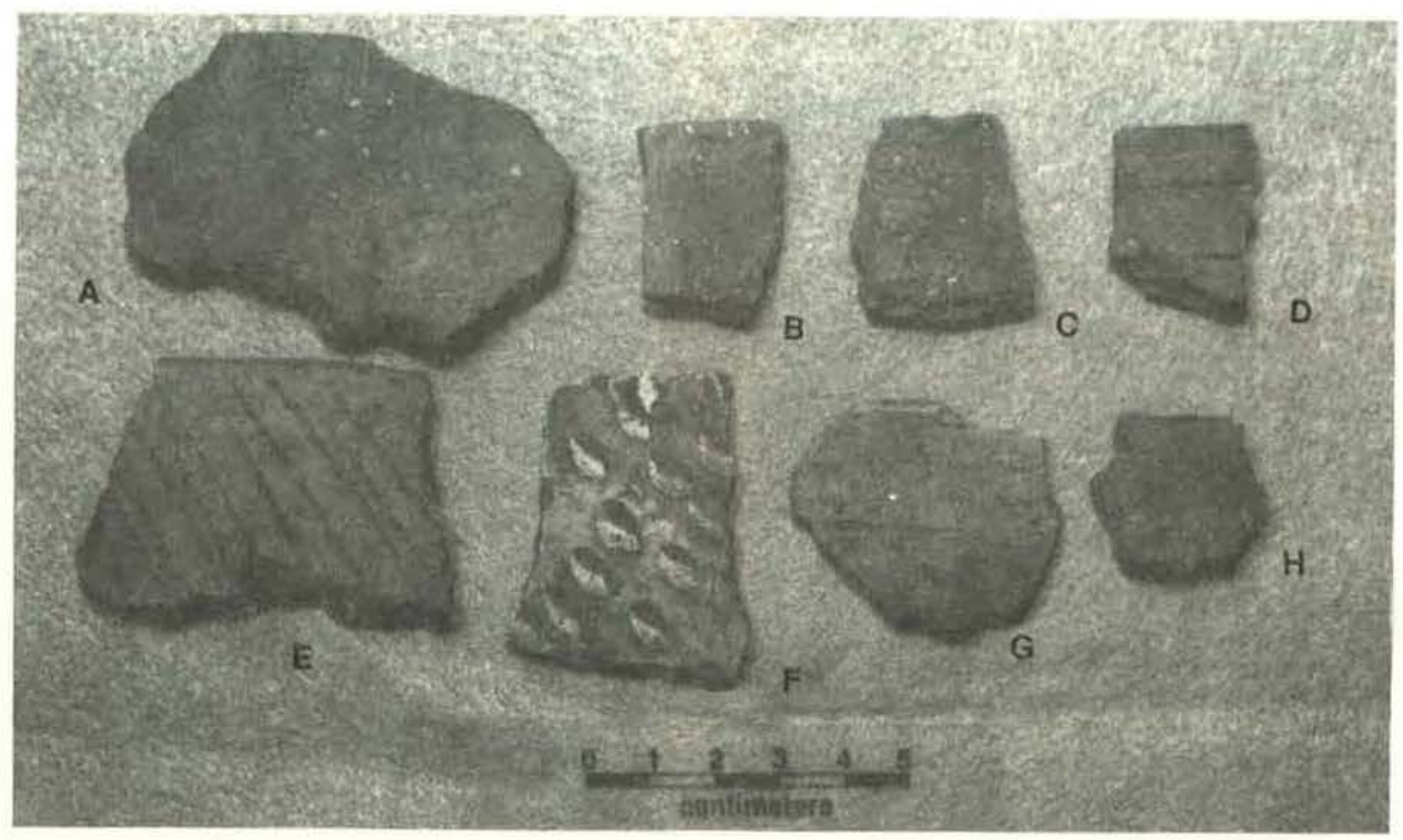

Figure 4. Plain and decorated rim sherds: Plain rims, 4a,b,c; incised rims, 4d,e,g,h; punctated rime, $4 f$.

it is doubtful they manufactured the dart point, however.

\section{CERAMICS}

Not including the burned clay and daub, 155 ceramic sherds were recovered in the limited investigations at the Griffin Mound site. The sherds are from well-made and well-fired bowls and jars which had been formed by coiling. Vessels were occasionally polished and/or burnished as a form of surface treatment, and a few appear to be plain. However, in general, it appears that most of the vessels at the site were probably decorated, at least along the rim. One large sherd from a plain bowl was recovered in Feature 1 (Figure 4a).

About $14 \%$ of the sherds $(n=22)$ have decorations on their exterior surfaces. The sherds are relatively small in size, which creates difficulties in discerning the type of decorative element (engraving, incising, etc.) as well as the stylistic motif (crosshatched lines, pendant triangles, horizontal lines, etc.) present in the assemblage, but the decorative elements include incising $(n=12$, $55 \%$ of the decorated sherds), engraving $(n=9,41 \%)$, and punctating $(n=1,4.5 \%)$.

Both diagonal and horizontal motifs are identified in the incised sherds (Figure 4). One large diagonally incised rim sherd was recovered from ST 4 (Figure $4 \mathrm{e}$ ), whereas horizontally incised rim and body sherds were found in ST 1 and in Unit $5 \quad(0-20 \mathrm{~cm}$ and $110-130$ $\mathrm{cm}$ bs). Other incised sherds without clear stylistic motifs were collected from the surface $(n=4)$ 


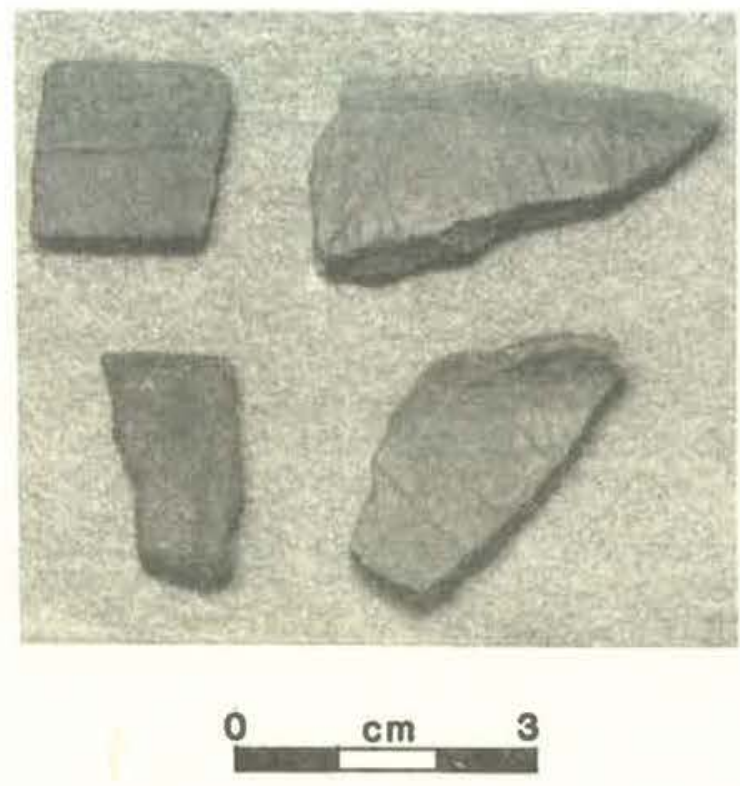

Figure 5. Engraved sherds from the Griffin Mound site: ST1, 5a,c; surface, $5 b, d$.

as well as lower levels of the midden in Unit 5. The incised sherds from Griffin Mound probably represent Canton Incised and Davis Incised types (Suhm and Jelks 1962). Vessels in these types are usually large bowls, although Canton Incised jars have been recovered in Caddoan assemblages in Northeast Texas. The rims of the incised vessels are straight with rounded or flat lips and 6-7 mm in thickness.

The single punctated sherd is from ST 4 (Figure $4 \mathrm{f}$ ). Decorations consist of parallel rows of broad fingernail punctations on the body of the vessel (probably a jar).

The nine engraved sherds are represented by several stylistic motifs: 1) thin horizontal lines on the rim, 2) diagonal lines beginning below the lip, and 3) opposing lines that extend down from the lip of carinated bowls to the carination point (Figure 5). The latter two motifs are common

on the Sanders Engraved type (Suhm and Jelks 1962), one of the more frequent decorated ceramic types in the Middle Caddoan period in the Cypress Creek Basin (Thurmond 1990:39). The engraved sherds are from polished and/or burnished bowls and carinated bowls with straight rims and either rounded or inverted lips. Rim thicknesses are 5-6 $\mathrm{mm}$. The engraved sherds were recovered from the following proveniences: Surface $(n=4)$, ST 1 $(n=2)$, and Unit $5,0-20 \mathrm{~cm} \quad(n=2)$ and $40-50 \mathrm{~cm} \quad(n=1)$.

The four plain rim sherds (surface $=1$; Unit $5,0-20 \mathrm{~cm}=1,90-100$ $\mathrm{cm}=1$, and $110-130 \mathrm{~cm}=1$ ) in the Griffin Mound ceramic assemblage are from bowls with vertical sides and flat to rounded lips (Figure 4). The exterior surface of the plain bowls is burnished. Based on rim thicknesses ranging from $4 \mathrm{~mm}$ $(n=1)$ to $8 \mathrm{~mm}(n=3)$, bowls occur in at least two different sizes.

Five different combinations of aplastic tempers were used in the manufacture of the Griffin Mound ceramics: 1) grog-bone-grit, 2)

Table 2. Decorative elements and temper data, Griffin Mound site.

\begin{tabular}{llll}
$\begin{array}{l}\text { Decorative } \\
\text { element } \\
\text { Temper }\end{array}$ & $\begin{array}{l}\text { Grog- Grog- Bone- Grog- Grit } \\
\text { bone- bone grit grit } \\
\text { grit }\end{array}$ & \begin{tabular}{l} 
grit \\
\hline
\end{tabular} \\
\hline
\end{tabular}

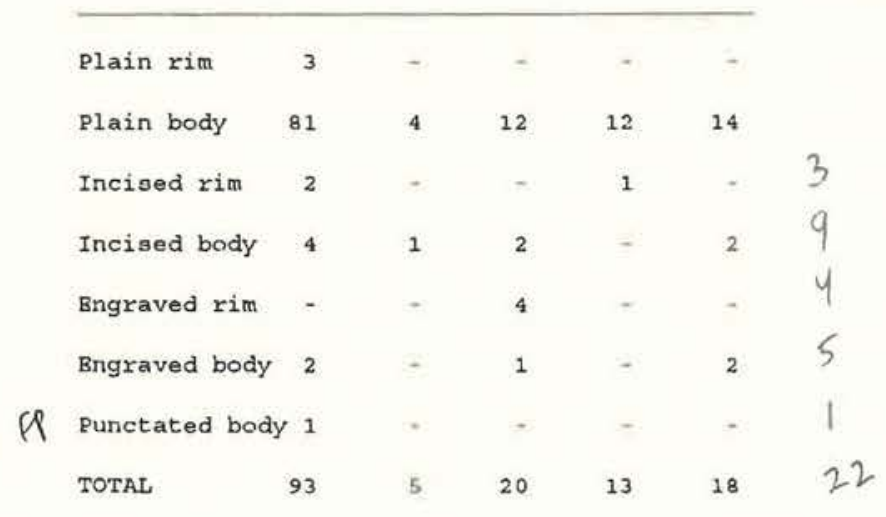


grog-bone, 3) bone-grit, 4) groggrit, and 5) grit (Table 2). In general, the ceramics from the site have a sandy paste with grit (small pieces of rock) inclusions, which apparently was added as a temper. The grog-bone-grit temper combination was most frequently chosen ( $62.4 \%$ of the sherds), particularly for the plain and incised vessels, followed by bonegrit (13.4\%) principally among the engraved sherds, grit (12.1\%) among plain and decorated sherds, grog-grit $(8.7 \%)$ for plain vessels, and grog-bone (3.4\%) in the plain and incised vessels.

These differences in temper and decorative treatment are also reflected in the data on sherd thickness by temper combinations. The thicker sherds (and vessels) are principally plain, incised, and punctated. They are tempered with grog-bone (mean=7.8 mm; $\mathrm{sd}=0.7 \mathrm{~mm})$, grog-grit (mean $=7.5$ $\mathrm{mm} ; \mathrm{sd}=1.4 \mathrm{~mm}$, and grog-bone-grit (mean=7.0 mm; $s d=0.8 \mathrm{~mm}$ ). The thinner sherds are mostly engraved carinated bowls. These have bone-grit (mean $=6.7 \mathrm{~mm} ; \mathrm{sd}=1.2 \mathrm{~mm}$ ) and grit (mean $=6.3 \mathrm{~mm} ; \mathrm{sd}=0.9 \mathrm{~mm}$ ) temper.

There are no clear changes across the site or within the midden in the use of the different ceramic temper combinations (Table 3 ), as grog-bone-grit is common across the site. While probably related to sample size problems, and the unique character of the Feature 1 archaeological deposits, it is interesting that about $91 \%$ of the sherds in Feature 1 are tempered with grog-bone-grit, compared to between 53 and $55 \%$ in the midden and plow zone, respectively. Many sherds from Feature 1 seem to be from one large, plain, grog-bone-grit tempered bowl, whereas the midden and plow zone sherds represent small parts of several different vessels.
One particularly notable characteristic of the Griffin Mound ceramics is the very high frequency of bone temper in the assemblage. About $79 \%$ of the sherds has some amount of burned bone added as a temper to the paste (Tables 2 and 3). Among Caddoan sites at Lake Fork Reservoir, about $40 \mathrm{~km}$ to the west in the upper Sabine

Table 3. Ceramic Temper Data, Griffin Mound Site.

\begin{tabular}{|c|c|c|c|c|c|c|}
\hline $\begin{array}{l}\text { Unit } \\
\text { Temper }\end{array}$ & $\begin{array}{l}\text { Grog- } \\
\text { bone- } \\
\text { grit }\end{array}$ & $\begin{array}{l}\text { Grog- } \\
\text { bone }\end{array}$ & $\begin{array}{l}\text { Bone- } \\
\text { grit }\end{array}$ & $\begin{array}{l}\text { Grog- } \\
\text { grit }\end{array}$ & Grit & Total \\
\hline \multicolumn{7}{|c|}{. } \\
\hline Surface & 11 & 1 & 7 & I & 7 & 27 \\
\hline ST1 & 1 & 2 & 2 & + & * & 5 \\
\hline ST2 & - & * & - & 2 & - & 2 \\
\hline $\mathrm{ST}_{3}$ & - & - & - & 1 & - & 1 \\
\hline ST4 & 5 & 2 & 1 & 2 & 1 & 11 \\
\hline \multicolumn{7}{|c|}{ Unit $5(\mathrm{~cm} \mathrm{ba})$} \\
\hline $0-20$ & 5 & - & 1 & 2 & 1 & 9 \\
\hline $20-30$ & - & + & 2 & - & + & 2 \\
\hline $30-40$ & 2 & - & - & 1 & 1 & 4 \\
\hline $40-50$ & 3 & - & - & 2 & 2 & 7 \\
\hline $50-60$ & 3 & . & $=$ & 1 & 1 & 5 \\
\hline $60-70$ & 4 & - & 3 & 1 & - & 8 \\
\hline $70-80$ & B & - & 1 & - & 3 & 12 \\
\hline $80-90 *$ & 4 & - & 2 & - & 1 & 7 \\
\hline $90-100$ & 11 & - & - & - & - & 11 \\
\hline $100-110$ & 2 & - & 1 & - & 1 & 4 \\
\hline $110-130$ & 34 & - & - & - & - & 34 \\
\hline TOTAL & 93 & 5 & 20 & 13 & 18 & 149 \\
\hline
\end{tabular}

* Does not include 6 small sherdlets from the flotation sample. 
Volume 5, Number 3

River arainage, bone temper ranged ca. $1-70 \%$ of the sherds from 29 site artifact clusters (Bruseth and Perttula 1981:Table 5-7). The percentage of bone temper in the majority of the clusters fell between $10-40 \%$ of the sherds. Through time, particularly after ca. A.D. 1200, use of bone temper decreased considerably, to the point that in the Late Caddoan Titus phase (ca. A.D. 1450-1600+) bone temper was present in less than $5 \%$ of the assemblage. Grog temper was overwhelmingly the temper of choice by that time. In another nearby example, bone temper was present in about $20 \%$ of the sherds from the Middle Caddoan component at the Ned Moody site (41WD577) along Mill Race Creek (Perttula and Gilmore 1988:Table A.4-15), ca. $30 \mathrm{~km}$ to the southwest. Obviously, larger samples from the Griffin Mound site, as well as sherd samples from other contemporaneous Middle Caddoan sites in the Little Cypress Creek valley and adjacent drainage bas ins, need to be obtained and analyzed to determine the temporal, technological, and functional significance of the apparently intensive use of bone as a temper in this locality.

\section{RADIOCARBON DATING}

A sample of 54 charred hickory nutshelis from $110-130 \mathrm{~cm}$ bs in Feature 1 was submitted to Beta Analytic Inc. for radiocarbon dating analysis. An uncorrected ${ }^{14} \mathrm{C}$ age of $820 \pm 80$ years B.P. (Beta-65018 ) was obtained from the
Feature 1 sample. The ${ }^{12} \mathrm{C} /{ }^{19} \mathrm{C}$ isotope ratio of -25.5 corrected the radiocarbon age to $810 \pm 80$ years B.P. The calibrated 1 sigma date for Feature 1 is A.D. 1222-1268 (Stuiver and Reimer 1993).

\section{INTERPRETATIONS AND CONCLUSIONS}

The limited archaeological investigations at the Griffin Mound site have demonstrated that it contains well-preserved midden deposits of probable Middle Caddoan age with a large, intact pit feature. The depth and extent of the midden, along with the abundance of stone tools and ceramic vessels found at the site, attest to a relatively intensive Caddoan occupation at Griffin Mound, although it is probable the occupation did not last much more than one or two generations (cf. Perttula et al. 1986:55). As is seen elsewhere in Northeast Texas at this time, habitation sites like Griffin Mound seem to represent small hamlets and farmsteads. They have structural remains, features for cooking and storage, and midden deposits, and are common along many of the major and minor streams in the region.

Caddoan sites dating to ca. A.D. 1200-1400 in the Cypress Creek Basin are relatively rare, however, and seem to be concentrated in the "upper reaches of Big Cypress Creek" (Thurmond 1990:227-228, Table 63). Thurmond (1990) speculates that the apparent clustering of Middle Caddoan sites in the basin may represent part of a discrete population group associated with the Keith (41TT11) and Hale (41TT12) mound centers near Mt. Pleasant, about $40 \mathrm{~km}$ north of the site. Perhaps the people who lived at the Griffin Mound site 
were part of a similar and contemporaneous Caddoan population which lived in the upper part of Little Cypress Creek valley. To further examine socio-political and settlement patterning questions, it is critical that a concerted program of identification, investigation, and dating of other Middle Caddoan period sites be completed in this part of the Cypress Creek Basin.

Because of likely changes in land control, and the activities of cows and wild hogs, it is doubtful that the Griffin Mound site can be preserved much longer.
We intend to complete additional investigations at the site in the near future, particularly by (1) expanding the excavation of the pit feature, (2) locating additional associated features, (3) acquiring more charcoal and nutshell samples in good context to refine the radiocarbon dating of the site, and (4) recovering larger and more representative samples of faunal and floral remains. The information that can be obtained froin these data sets will contribute towards a better understanding of Caddoan lifeways in the Little Cypress Creek valley of Northeast Texas.

\section{ACKNOWLEDGMENTS}

We first thank $\mathrm{Mr}$. and Mrs. Merrit Griffin for giving us access to their land, and permission to carry out these archeological investigations on their property.
Thanks also to Bob D. Skiles and Joshua $S$. Nelson for assisting with the 1993 excavations of the site.

\section{REFERENCES CITED}

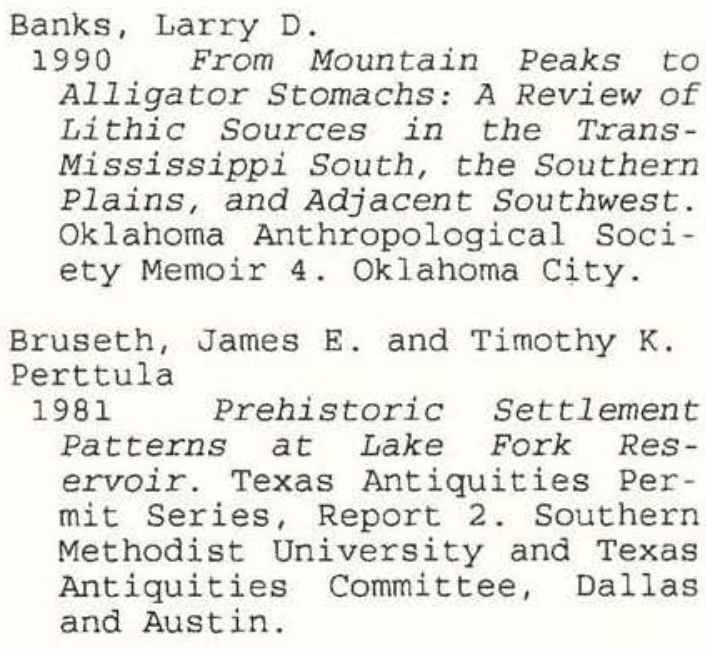
Alligator Stomachs: A Review of Lithic sources in the TransMississippi South, the Southern Plains, and Adjacent Southwest. Oklahoma Anthropological Society Memoir 4. Oklahoma City.

Bruseth, James E. and Timothy K. Perttula

1981 Prehistoric Settlement Patterns at Lake Fork Reservoir. Texas Antiquities Permit Series, Report 2. Southern Methodist University and Texas Antiquities Committee, Dallas and Austin.

Fields, Ross C., Eloise F. Gadus, L. Wayne Klement, C. Britt Bousman, and Jerrilyn B. McLerran 1993 Excavations at the Tick, Spike, Johns Creek, and Peerless Bottoms Sites, Cooper Lake Project, Delta \& Hopkins Counties, Texas. Reports of Investigations 91. Prewitt \& Associates, Inc., Austin.

Horizon Environmental Services, Inc.

1993 Cultural Resources of the Proposed Lake Gilmer Project, Upshur County, Texas. Job No. 910055. Horizon Environmental Services, Inc., Austin. 
Volume 5, Number 3

1994 Test Excavations at Pro posed Lake Gilmer, Upshur County, Texas. Job No. 930105. Horizon Environmental Services, Inc., Austin.

Nelson, Bo

1993 The GG Site (41UR136): A Surface Evaluation in the Little Cypress Creek Drainage, Upshur County, Texas. The Cache, Collected Papers on Texas Archeology 1:73-76. Office of the State Archeologist, Texas Historical Commission, Austin.

Nelson, Bo and Timothy K. Perttula 1993a Site 4lUR136, a Titus Phase Site in the Little Cypress Creek Basin. Caddoan Archeology Newsletter III(4): 11-16.

1993b The Z.V. Davis-McPeek Site, an Early Caddoan Mound Site in the Little Cypress Creek Valley, Upshur County, Texas. Notes on Northeast Texas Archaeology 2:50-65.

Perttula, Timothy $\mathrm{K}$. and Kathleen K. Gjlmore

1988 Archaeological Survey Along Mill Race Creek and Tributaries, Wood County, Texas: 19871988. Contributions in Archaeology 6. Institute of Applied Sciences, University of North Texas, Denton.

Perttula, Timothy K., Bob D. Skiles, and Bonnie C. Yates

1993 The Goldsmith site (41WD208): Investigations of the Titus Phase in the tpper Sabine River Basin, wood County, Texas. Bulletin of the Texas Archeological Society $61: 139-191$.
Perttula, Timothy K., Bob D. Skiles, Michael B. Collins, Margaret $\mathrm{C}$. Trachte, and Fred Valdez, Jr.

1986 "This Everlasting Sand Bed": Cultural Resources Investigations at the Texas Big Sandy Project, Wood and Upshur Counties, Texas. Reports of Investigations 52. Prewitt \& Associates, Inc., Austin.

Stuiver, Minze and Paula J. Reimer 1993 Extended ${ }^{14} \mathrm{C}$ Database and Revised CALIB Radiocarbon Calibration Program. Radiocarbon $35: 215-230$

Suhm, Dee Ann and Edward B. Jelks 1962 Handbook of Texas Archeol ogy: Type Descriptions. Texas Archeological Society Special Publication 1 and Texas Memorial Museum Bulletin 4. Austin.

Thurmond, J. Peter

1985 Late Caddoan Social Group Identifications and Sociopolitical Organization in the Upper Cypress Basin and its Vicinity, Northeastern Texas. Bulletin of the Texas Archeological Society $54: 185-200$.

1990 Archeology of the Cypress Creek Drainage Basin, Northeastern Texas and Northwestern Louisiana. Studies in Archeolgy 5. Texas Archeological Research Laboratory, The University of Texas at Austin.

Turner, Ellen sue and Thomas R. Hester

1993 A Field Guide to Stone Artifacts of Texas Indians, 2nd edition. Gulf Publishing Company, Houston. 